\title{
Sciendo
}

PROCEEDINGS OF THE LATVIAN ACADEMY OF SCIENCES. Section B, Vol. 73 (2019), No. 3 (720), pp. 195-206.

DOI: $10.2478 /$ prolas-2019-0032

Review

\section{PLUM RESEARCH AND GROWING IN LATVIA}

\author{
Edìte Kaufmane, Ilze Grāvìte, and Laila Ikase \\ Institute of Horticulture, Latvia University of Life Science and Technologies, 1 Graudu Str., Ceriṇi, Krimūnu pag., Dobeles nov., LATVIA \\ Corresponding author, edite.kaufmane@llu.Iv
}

Contributed by Edīte Kaufmane

\begin{abstract}
Plums have been commercially grown in Latvia since the $19^{\text {th }}$ century. Plantations expanded especially in the 1920s-1930s. At that time, many cultivars were introduced, mostly from Western Europe. After the severe winters of 1939/40, 1941/42, 1955/56, and 1978/79, the plum orchard area significantly decreased because of a lack of winter-hardy cultivars. For this reason, cultivars from Russia, Belarus, and Estonia were introduced. Among the old landraces, highly winter-hardy 'Latvijas Dzeltenā Olplūme' is still important. Previously it used to be productive and had good fruit quality. Unfortunately, nurseries often propagated the hardiest clones, which lacked productivity. As Latvian consumers love yellow plums, at present breeding and propagation of productive clones from old orchards is ongoing. In the mid-20 century, active plum breeding started in Latvia, crossing hardy genotypes with high quality donors. From this period 'Lāse' and 'Minjona' are still grown. Since the 1980s, plum breeding has been undedrtaken at the Institute of Horticulture. The crossing work in plums concentrated on the hexaploid group, aiming to combine large fruit size with good flavour, different time of ripening (in particular, early to medium late) and and good winter-hardiness. New cultivars include 'Sonora', 'Ance', and 'Adelyn', which have good quality, and productivity 20-30 kg per tree, and in some years up to $70 \mathrm{~kg}$ per tree.

The most widely used rootstocks are seedlings of Prunus cerasifera Ehrh. ssp. divaricata C.K. Schneid., which is more hardy that the common myrobalan plum. These rootstocks have good compatibility with most cultivars except gages, and are adapted to different soil types and are disease tolerant. Their drawback is a long growth season which reduces winter-hardiness of grafted cultivars. Also, they tend to form suckers around the stem. A hardy seedling PU-20651 (P. salicina ssp. ussuriensis $\times$ P. cerasifera) was bred at the Institute, which was shown to slightly reduce tree vigour. Testing of several Western European and Russian rootstocks did not result in their introduction into production. Trials are presently being carried out with size-reducing rootstocks originated from cultivar Wangenheim VVA-1, Weiwa, S766, and M633.

Commercial production of plums in Latvia is relatively small, as the area of orchards is the smallest among fruit trees. Plums are grown mostly for fresh consumption, with a small part for jams, yoghurt, and ice-cream additives. Fruits are sold mostly in small shops, markets and at farms. The main reason is the climate, which allows growing of a limited range of cultivars that tolerate the $-30^{\circ} \mathrm{C}$ winter temperatures in some years (about every five years). About 20 cultivars are grown commercially; the share of the six most popular plum cultivars is $69 \%$ of the total plum production. In recent years, plantations of new cultivars developed at our Institute have expanded, especially regarding the early ripening cultivar 'Ance'.
\end{abstract}

Key words: fresh plums, growing areas, cultivars, rootstocks, winter-hardiness.

\section{INTRODUCTION}

Plum production at northern latitudes, where Latvia is situated, is restricted by climatic factors. Introduction and adaptation of cultivars from central and southern parts of Europe or Northern America are very difficult because of their un- satisfactory hardiness in the climate of Latvia, while winterhardy cultivars from Russia and Belarus are often lacking in fruit quality. On the other hand, Latvian climatic conditions are favourable for breeding and growing of plums adapted to the local climate. Commercial plum growing in Latvia is constantly developing. However, in spite of long-term 
breeding work, the variety assortment of plums is still rather scarce, and particularly, there is a lack of plum cultivars suitable for sale at supermarkets, with large and tasty fruits and satisfactory flesh firmness.

Plums have been commercially grown in Latvia since the $19^{\text {th }}$ century. Plantation areas expanded at a large rate in the 1920s-1930s. In 1935, there were 1046 mill. plum trees with average yield of $14-18 \mathrm{~kg} /$ tree. Nursery plant production was 12 thousand plum trees, while for 60-70 thousand trees could not be met due to shortage of rootstocks. About $50 \%$ of the plums was the landrace 'Latvijas Dzeltenā Olplüme', and the others were Western European cultivars. After the severe winters of 1939/40, 1941/42, when in some places temperatures fell below $-40{ }^{\circ} \mathrm{C}$, the area of plum orchards decreased by $50 \%$. The reasons were lack of hardy cultivars and use of growing technologies introduced from countries with different climate (Sudrabs, 1947).

Extreme winters occurred also in the following years, which created the need for breeding and introduction of climate adapted cultivars.

\section{CULTIVARS}

History of plum variety assortment formation in Latvia. In early 19th century, the first nurseries for fruit tree production were established in Rīga and in the countryside nurseries of J. Zigra (in 1803), K. H. Wagner (in 1816) and C. W. Schoch (in 1836). In the 1870 s, nurseries were founded by A. von Sievers at Kārḷi manor near Cēsis (Wenden), and by S. Klevers in Durbe. Thanks to the large Rìga nurseries that produced plants for the whole Russian Empire, the best Western European and American plum cultivars were introduced to Latvia. Already in 1870, the Schoch nurseries offered 28 plum cultivars (Anonymous, 1870-1871), and in the next years their number approached 100. The assortment of plum cultivars in Latvia since then has been continuously changing, as extreme winters killed cultivars lacking hardiness, and those that did not mature properly in the short summers also were discarded (Kārkliņ̌s et al., 2007).

S. Klevers, who was the first Latvian horticulture publicist, in 1881 recommended to plant the following plum cultivars: with yellow or green fruits _ 'Mirabelle de Nancy', 'Mirabelle de Metz', 'Dzeltenā Olplūme', 'Green Gage'; with red and blue fruits — 'Sarkanā Olplūme', 'Perdrigon', 'Tumši Zilā K,ēnina Plūme' (now unknown), and 'The Czar' (Klevers, 1881).

J. Pengerots in his book Auglı dārzs recommended: 'Green Gage', 'Reine-Claude de Bavay', 'Vidzemes Dzeltenā Olplūme', 'Queen Victoria', 'Kirke', 'Reine des Mirabelles', 'Jefferson', 'Imperial Ottomane', 'Hungarian Prune', 'Anna Späth', and pointing out that the latter two mature only during warm autumns (Peņǵgrots-Svešais, 1904).

J. Sudrabs wrote, in 1914: "In some places of Vidzeme [i.e. Central and Northern Latvia] plum growing also may be profitable, but one cannot rely on them; the safest cultivars would be — 'Peach Plum', 'Victoria', 'Green Gage', 'Kirke', 'Vidzemes Dzeltenā Olplūme' ". He also mentioned cultivars 'Duke of Edinburgh' (syn. 'Prince of Wales'), 'Bühler Frühzwetsche', and 'The Czar' (Sudrabs, 1914). Taking into account the damage in severe winters, the Department of Agriculture, in 1921, compiled a list of fruit crop standard cultivars recommending for growing in all regions of Latvia the following plums: 'The Czar', 'Duke of Edinburgh', 'Victoria', 'Green Gage', 'Ontario', 'Mirabelle de Metz', and 'Jefferson' (Sudrabs, 1943). Later severe winters showed that only a few of them were hardy enough.

After the winter of $1928 / 29$, in which stone trees suffered heavy damage, the territory of Latvia was divided into five climate zones for growing apples and pears, but the list of recommended plum cultivars was still recommended for the whole territory, as there was insufficient data about plum hardiness in regions.

After the severe winters of 1939/40, 1941/42, and 1955/56, the plum orchard area significantly decreased. After the winter of $1955 / 56$, it was concluded that cultivars hardy in whole territory were 'Ziedture' ( $P$. domestica ssp. insititia), 'Mirabelle de Nancy', 'Latvijas Dzeltenā Olplūme', 'Kārsavas' (clone of 'Vengerka Moskovskaya'), and 'Victoria'; perspective cultivars were 'Skoroplodnaya' and Varakḷāni clone of 'Latvijas Sarkanā Olplūme'. Cultivars recommended for only southwest and western zones were 'Reine-Claude d'Oullins' and perspective cultivars were 'The First', 'Experimentalfältets Sviskon', and 'Aizputes', and in the southwest also 'Kirke'. In the central and eastern zones where most plums could not survive, 'Viḷakas Plūme' (clone of 'Skorospelka Krasnaya') was recommended as very hardy, but with relatively poor fruit quality. 'Perdrigon', which later proved itself as a highly winter-hardy cultivar, was recommended only for the central zone, as there were only short-term observations (Kārkliņš, 1958; 1966).

After the winter of $1978 / 79$, when temperature in some regions fell even below $-40{ }^{\circ} \mathrm{C}$, hardy survivors were 'Latvijas Dzeltenā Olplūme', 'Viḷakas', 'Perdrigon' and 'Tartu Punane' (Skrivele, 1982a; 1982b).

The last extremely cold winter was in 1986/87, again close to $-40{ }^{\circ} \mathrm{C}$. Very good or good hardiness was observed for landraces 'Latvijas Sarkanā Olplūme', 'Latvijas Dzeltenā Olplūme', Russian cvs. — 'Otborny Seyanets Evrazii', 'Volzhskaya Krasavitsa', 'Okskaya', Estonian cvs. — 'Polli Viljakas', 'Vilnor', 'Liisu', also 'Experimentalfältets Sviskon', 'The Czar' and 'Stanley' (Jekovičs, 1988; Kārkliņš et al., 2007).

Introduction of cultivars in the $2^{\text {nd }}$ half of the $20^{\text {th }}$ century and beginning of the $21^{\text {st }}$ century. In the second half of the $20^{\text {th }}$ century, many Estonian and Lithuanian plum cultivars were introduced to Latvia, where they were tested at Pūre Horticulture Research Station by M. Skrīvele. The 
best suitability to Latvian climate was shown by 'Ave', 'Julius', 'Polli Viljakas', and 'Vilnor' from Estonia. The most promising Lithuanian cultivar was 'Rausve' (Gronskis et al., 1988).

'Renklod Sovetsky', 'Krasnoslobodskaya', and 'Sentyabrskaya' were considered as promising cultivars from Russian breeding programmes, as they were well-adapted to the Latvian climate and had satisfactory fruit quality. These cultivars were examined in trials at Pūre by U. Dēķens (Dēķens, 1999).

During the same period, evaluation of Russian cultivars from the so-called Eurasia group was conducted. Eurasia plums were developed by crossing of diploids (mostly cv. 'LaCrescent') with hexaploid plums and subsequently backcrossed to obtain hexaploid material. From cultivars tested at Dobele, the most promising were 'Aleinaya', 'Zarechnaya Rannaya', and 'Startovaya'. The main reasons of their selection were early ripening, as well as good winterhardiness, easy tree shape and fruit quality (Ikase and Kaufmane, 1994; Kārklinšs et al., 2007).

Among diploid plum $(2 \mathrm{n}=16)$ species, only introduction of more hardy Russian cultivars was partially successful. Among these cultivars, the Japanese plum subspecies Ussurian plum (Prunus salicina ssp. ussuriensis (Kov. et Kost.) Erem.) was characterised as cold-hardy, but in Latvia showed sensitivity to temperature fluctuations in late winter and susceptibility to diseases. Only one cultivar ('Skoroplodnaya' became commercially successful in Latvia, and only in continental regions (Jekovičs, 1972). Later, interspecies hybrids from Russia were introduced, whereby Japanese and Ussurian plums were crossed with myrobalan plum $P$. cerasifera Ehrh. (high disease tolerance), P. americana Marsh., P. nigra Ait., P. simonii Carr., etc. The interspecies hybrids were better adapted in Latvia, but still were susceptible to flower bud damages. The most stable production was shown by 'Kometa Kubanskaya' (syn. 'Kometa'). This species was widely grown in commercial orchards (Ikase, 1998; Kārkliņš et al., 2007).

At the end of the 1990s, testing of cultivars and hybrids selected in Sweden was started at Dobele. 'Jubileum', one of the most popular commercial cultivars in Scandinavia, and characterised by high fruit quality was considered as most promising for growing in Latvia (Kaufmane et al., 2003).

Since 2008, cultivars created by the outstanding German breeder Walter Hartman were tested at the Institute of Horticulture in Dobele. Their greatest values were resistance to sharka virus (PPV), good fruit quality and high sugar content. Presently, the most promising cultivar is 'Tegera', which has acceptable winter-hardiness in Latvian conditions and fruits with good storage and suitable for drying $\left(17\right.$ Brix $\left.^{\circ}\right)$. Good results were shown also by 'Hanita', which has high and regular production and very high fruit quality $\left(20 \mathrm{Brix}^{\circ}\right)$, and by hybrid H 3753 (19.2 Brix $\left.^{\circ}\right)$. In years with a long and warm autumn, the late-ripening cultivars 'Haganta' and 'Habella' also showed good results, but in some cooler seasons their fruits did not mature (Grāvīte and Kaufmane, 2017).

Regularly repeating severe winters have proven that hardy cultivars are needed in the Latvian climate, while consumers need atractive, tasty fruits. For this reason, breeding of native plum cultivars has been conducted, along with testing of cultivars introduced from abroad.

Plum breeding and clone selection in Latvia. The landrace 'Latvijas Dzeltenā Olplūme' (Figs. 1-2) has been grown in Latvia for a long time. It is not known where and when the cultivar was formed. It was grown under different names: 'Vidzemes dzeltenā olu plūme', 'Vidzemes dzeltenā', 'Zemnieku plūme' etc., at least 100 years or maybe even 200 years ago. In Lithuania it is also considered as an old local cultivar and called 'Vietine Geltonoji'. In Estonia it is considered as a landrace from Vidzeme (Livland), and its Estonian name is 'Liivi kollane munaploom'. In Russia and Belarus, it is also considered as a cultivar of local origin and called 'Ochakovskaya Zholtaya' or 'Ochakovskaya Belaya' (Skrīvele and Dēkēena, 2017). It is similar but not necessarily indentical to other old yellow egg plums in Europe, e.g. 'Allmänt Gulplommon', which has been grown in Sweden possibly since the Middle Ages (Nilsson, 1989). In the course of centuries it has been propagated both by root suckers and seeds, and the most winter-hardy genotypes with better fruit quality have been selected by many growers. In the 1950s, the researcher of the Institute of Biology, Academy of Sciences Antons Spolitis organised expeditions to search for Latvian plum landraces to evaluate. It was found that most 'Latvijas Dzeltenā Olplūme' trees were found in Northern Latvia around Limbaži, Aloja, Smiltene, Alūksne, and Rūjiena, but also around Aizpute (Western Latvia) and Ludza (Eastern Latvia). The most productive clones with the largest fruits were selected during the expeditions, but these perished in the following severe winters.

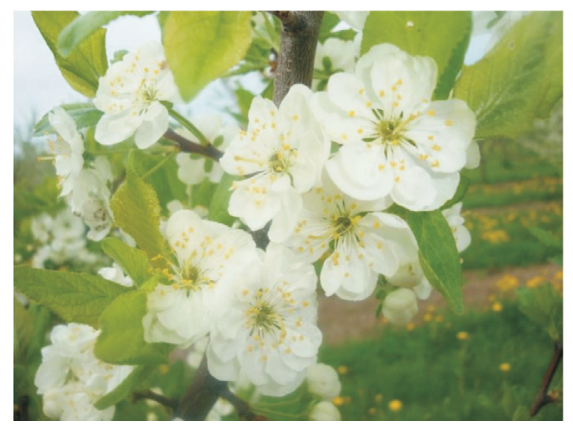

Fig. 1. 'Latvijas Dzeltenā Olplūme': semi-double flowers.

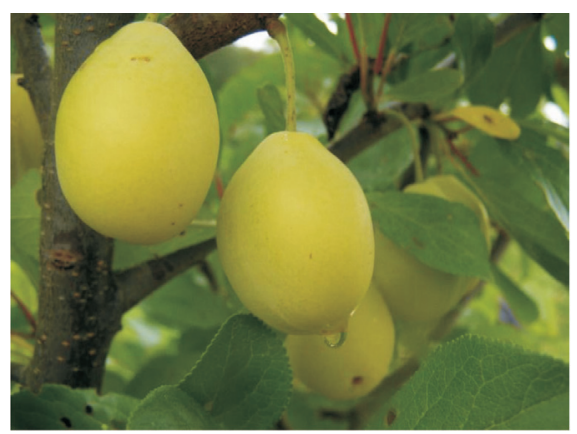

Fig. 2. 'Latvijas Dzeltenā Olplūme’: fruits. 


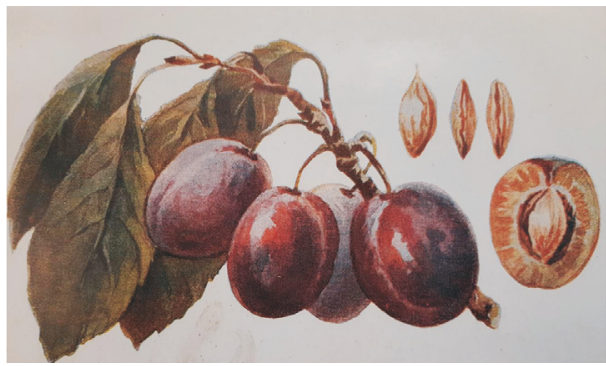

Fig. 3. 'Kārsavas Sarkanā plume'. From: Kārkliṇš J. (1958).

Typical traits of the landrace are late flowering and sterile pollen (Spolìtis et al., 1955).

Two best clones of another landrace, 'Latvijas Sarkanā Olplūme', were also selected during the expeditions 'Varaklānu' ('Varakḷānu Sarkanā') and 'Krustpils' ('Krustpils Sarkanā'). These clones are more winter-hardy and have better fruit quality than other clones of this landrace. A clone 'Kārsavas' ('Kārsavas Sarkanā') (Fig. 3) was selected from 'Vengerka Moskovskaya', and clone 'Vilakas' from 'Skorospelka Krasnaya'. In Aizpute, a plum cultivar 'Aizputes' was found, and in the orchards of Vidzeme also cultivar 'Agrā Sārtā'. In all regions of Latvia, different landraces and clones of small blue damson plums called "būkas" or "krīḳes" (Prunus domestica ssp. insititia (L.) C. K. Schneid.) have been propagated by root suckers during a long time period. Those with the largest fruits were selected as cultivars — 'Kurzemes Būka', 'Vidzemes Būka', 'Latgales Būka' (Spolītis et al., 1955).

In the course of his research of plum fertilisation biology, A. Spolitis made numerous crosses. From the obtained hybrids, promising variety candidates were selected: 'Lāse' registered in Latvia, and 'Zilā Lāse' (Spolīša 20-1) (Spolītis, 1978; Skrīvele et al., 1999).

Breeder Pēteris Upītis in Dobele also investigated Latvian plum landraces, and selected the damson plum 'Ziedture'. He also conducted large-scale hybridisation between cultivars and plum species (Mežapuķe, 1969). After his death, since the 1980s, plum breeding at Dobele was continued by Edite Kaufmane . Cultivars 'Zemgale' and 'Minjona' were selected and registered from hybrids of P. Upītis (Skrīvele et al., 1999).

The main breeding method of P. Upītis was sowing of open-pollinated seeds. In this way, he obtained relatively winter-hardy and highly productive hybrids of diploid plums - Caucasian subspecies of myrobalan plum (Prunus cerasifera Ehrh. ssp. divaricata C. K. Schneid.), Ussurian plum (Prunus salicina ssp. ussuriensis (Kov. et Kost.) Erem.) and their hybrids with other diploid species. From these hybrids, Laila Ikase selected cultivars 'Inese' and 'Agrā Dzeltenā', previously registered in Latvia (Ikase, 1991; 1993). Now, 'Agrā Dzeltenā' is growing only as polleniser. In breeding of red-leaf myrobalan plum, good results were achieved by Roberts Āboliņš and Aleksandrs Maizītis at Iedzēni, obtaining the cultivar 'Spīdola', which is still very popular.
Latvian genetic resources collection of diploid plums includes 22 cultivars and hybrids of Latvian origin, obtained from open-pollination or found as chance seedlings. The most interesting is 'Alvis' (syn. 'Veinberga') — a very hardy polleniser. The red leaf ornamental plum cultivars 'Liesma' and 'Gunta' obtained at the Institute of Horticulture are more winter hardy than 'Spīdola'. A winter-hardy hybrid of black apricot $P . \times$ dasycarpa MA-1 also was selected at the Institute. Unfortunately, all Latvian diploid plums have fruits too small for commercial production and can be used only for processing (Kaufmane, et al., 2002).

In the end of 1990s, the following aims were defined for plum breeding at the Institute:

- Cultivars adapted for growing in Latvia (including high winter-hardiness of flower buds, resistance of trees to low temperatures and harsh temperature changes during the winter-spring period).

- Fruit quality suitable for commercial growing.

- Resistance to the most important diseases.

- Ripening during an extended period of time (the main accent is laid on early maturation).

- Tree habit easy for training and cultivation.

- High degree of self-fertility.

During 1996-2001, a common domestic plum breeding programme with Swedish breeders was carried out. As a result, four new cultivars were released from more than 100 perspective hybrids. The obtained cultivars 'Sonora', 'Adelyn', and 'Ance' are suitable for commercial growing in whole territory of Latvia. In 2017, these cultivars were registered in Latvia. 'Lotte' has tasty and good quality fruits, but its winter-hardiness is not satisfactory in the entire territory of Latvia. It can be recommended for locations with the most favourable conditions (Kaufmane et al., 2012). Application for registration of following two new cultivars from this programme were made in 2016 and 2017 and currently are being tested through the DUS test: 'Laine', which is suitable for commercial cultivation, and 'Zane', which is suitable for growing in home gardens. In recent years, new cultivars have been planted in commercial orchards, and particularly the early ripening 'Ance'.

\section{POLLINATION}

Most of the plum cultivars grown in Latvia are partially or completely self-sterile. Knowledge of the flowering time and suitability of some cultivars as pollenisers is necessary for regular and high production. Numerous studies about pollination and fertilisation have been carried out and the most suitable pollenisers for new cultivars have been examined (Karklins et al., 2007; Gravite and Kaufmane, 2013). Plum cultivars are grouped as very early, early, medium early, medium late and late flowering. Flowering time can highly differ among years. In commercial plantations, it is 
Table 1

GROUPING OF PLUM CULTIVARS BY THEIR FLOWERING TIME IN LATVIA

\begin{tabular}{l|l}
\hline \multicolumn{1}{c|}{ Flowering time } & \multicolumn{1}{c}{ Cultivars* } \\
\hline Very early & $\begin{array}{l}\text { Diploid plums: Agrā Dzeltenā, Alvis, Kometa, } \\
\text { Mara, Naidyona, Skoroplodnaya, Spīdola }\end{array}$ \\
\hline $\begin{array}{l}\text { Early and me- } \\
\text { dium early }\end{array}$ & $\begin{array}{l}\text { Ave, Aleinaya, Ance, Adelyn, Duke of Edinburgh, } \\
\text { Experimentalfältets Sviskon, Jubileum, Julius, } \\
\text { Kārsavas, Krasnoslobodskaya, Minjona, Oda, } \\
\text { Renklod Ranny Donetsky, Renklod Uljanishscheva, } \\
\text { Sonora, Reine-Claude d'Oullins (in some years), } \\
\text { Victoria, Zarechnaya Rannaya, Zemgale }\end{array}$ \\
\hline Medium late and & $\begin{array}{l}\text { Althans Reine-Claude, Kijevas Vēlā, Lāse, Latvijas } \\
\text { Dzeltenā Olplūme, Lotte, Mirabelle de Nancy, On- } \\
\text { tario, Okskaya, Perdrigon, Sentyabrskaya, Stanley, } \\
\text { Reine-Claude d'Oullins (in some years), Washing- } \\
\text { ton, Green Gage }\end{array}$
\end{tabular}

* In bold - cultivars which are good pollinators

recommended to group cultivars according to their flowering time (Table 1). Closeness of a suitable polleniser is especially important in cool and rainy spring when the pollen is washed off the pistils (Feldmane et al., 2015). 'Victoria', the most common cultivar in Latvia is self-fertile and a good polleniser for all medium early flowering cultivars. For pollination of diploid plums, cultivars of the same group with good pollen quality are recommended (pollen germination of diploid plums often is low), but it is more common that pollenisers are seedlings of myrobalan plum (P. cerasifera ssp. divaricata) (Karklins et al., 2007).

Pollination trials with new cultivars indicated that the only cultivar with self-fertility is 'Sonora' (33.5\%). The best pollination results for cultivar 'Adelyn' were found in combination with cultivar 'Victoria' as a polleniser (average fruit set \% after June drop - 66.5\%). Cultivar 'Lotte' showed the best results with 'Minjona' as a polleniser (46.6\%), and 'Sonora' with 'Experimentalfältets' (53.9\%) (Grāvìte and Kaufmane, 2013). Recent research showed that 'Ance' is partially self-fertile; in favourable years fruit set with selfpollination was $32 \%$, in less favourable years $-0 \%$.

Also, genotyping by $S f$ (self-incompatibility) gene markers has been conducted at the Institute of Horticulture. A total of 99 plum accessions were genotyped: 7 diploid and 92 hexaploid plums with markers developed for different Prunus species. Future development is aimed at detection of plum self-incompatibility groups by allele specific genotyping (Kota and Lacis, 2013).

\section{ROOTSTOCKS}

The most used rootstock in Latvia is seedlings of Prunus cerasifera Ehrh. ssp. divaricata C. K. Schneid., which is hardier than the common myrobalan plum. This rootstock has good compatibility with most cultivars except gages. It is also well adapted to different soil types. It is disease tolerant. A drawback is due to a long growth season, which re- duces winter-hardiness of grafted cultivars and tendency to form suckers around stems.

The hardy seedling PU-20651 (P. salicina ssp. ussuriensis $\mathrm{x}$ $P$. cerasifera) has been selected at the Institute of Horticulture, which slightly reduces tree vigour (Kaufmane et al., 2007a).

Testing of several Western European and Russian rootstocks at the Institute of Horticulture during the period of 1995-2015 (St Julian A, St Julian GF 655/2, Myruni, AP-1, SVG 11-19, OP 23-23, Druzhba) did not show the expected results in production, and only St Julian GF 655/2 and AP-1 had satisfactory winter-hardiness (Kaufmane et al., 2007).

Dz. Dēkena performed long-term trials with cultivars 'Victoria' and 'Kometa' on 16 rootstocks of different origin and vigour. The best results for a complex set of parameters (winter-hardiness of tree and generative buds, productivity, fruit set etc.) in Latvia's conditions for both cultivars were recorded for the vigorous rootstock 'Brompton', as well as 'Wangenheim', which reduced tree vigour (Dēkena et al., 2017). A study with several Reine-Claude type cultivars showed that tree vigour on 'Wangenheim' rootstock was reduced aproximately $30 \%$, and that the yield per tree of all cultivars was also lower.

Current trials are being continued with 'Wangenheim' rootstocks and size-reducing VVA-1, Weiwa, S766 and M633. Preliminary results showed that: (1) the most vigorous rootstocks were $P$. cerasifera and Weiwa; (2) other rootstocks had no significant differences in vigour; (3) 'Victoria' had significantly smallest trees on VVA-1; (4) 'Jubileum' showed significant differences among rootstocks (VVA-1 decreased TCSA about 30\%; S 766 decreased TCSA about $15 \%$ compared with trees of seedling rootstock $P$. cerasifera; (5) the rootstocks P. cerasifera, S766 and M633 showed higher occurrence of suckers in both years of testing. An effect of cultivar on root suckering was not significant.

\section{ORCHARD MANAGEMENT}

In the period of 1945-1991, research of plum growing technologies involving planting distances, tree training, fertilising, maintenance of tree rows and alleyways was conducted at the Pūre Horticulture Research Station. At that time plums were grown only on seedlings of $P$. cerasifera Ehrh. spp. divaricate (Fig. 4). Planting distances for vigorous cultivars were $4 \times 6 \mathrm{~m}$, but for weaker growing cultivars $-3 \times$ $5 \mathrm{~m}$. In alleyways, it was recommended to maintain bare fallow to keep free of plant growth within tree rows and to grow intercrops between the tree rows (Gronskis and Üdris, 1988). Often it was recommended to train trees as bushes to reduce winter damages (Jekovičs, 1972).

In the late 1990s, research of plum growing technologies was started at Dobele, Institute of Horticulture. The main focus was on the effect of different cultivar-rootstock combinations on fruit quality, productivity, tree training and 


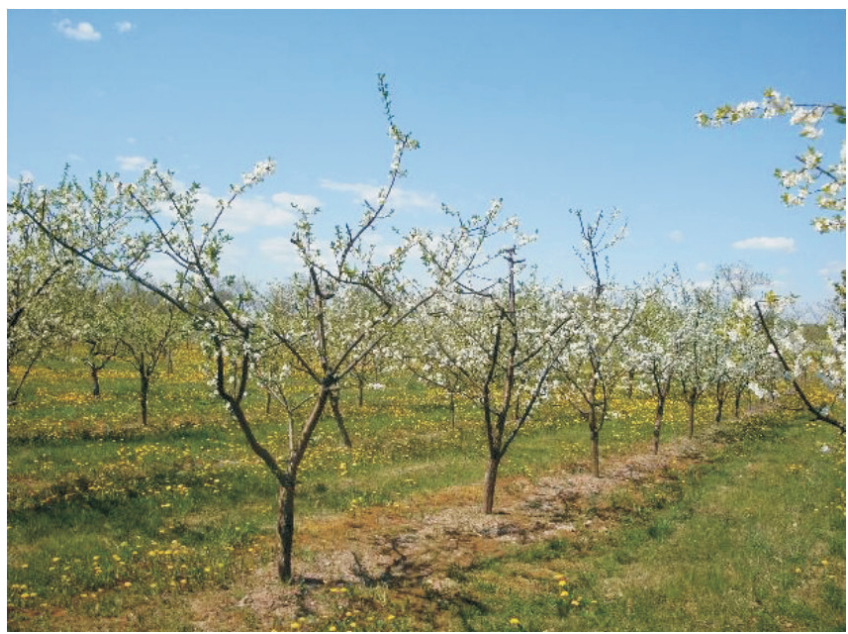

Fig. 4. Typical Latvian plum orchard on P. cerasifera rootstocks.

various methods of soil maintenance in rows. At present in Latvian conditions plum seedlings of $P$. cerasifera Ehrh. spp. divaricata are recommened to plant at 3-4 $\mathrm{m} \times 4-5 \mathrm{~m}$ distances: 500-830 trees per ha, depending on tree vigour. The most popular crown shapes are vase and spindle. Taking into account the Latvian climate, suitable trunk height for plums is $60-80 \mathrm{~cm}$. Grass is grown in alleyways, while tree rows are maintained free of weeds by mulching, herbicides or mechanically (Gravite and Skrivele, 2015; Skrīvele and Rubauskis, 2015).

Nowadays trials on different crown shapes, and their influence on productivity and fruit quality are carried out at the Institute. The aim of this research is to develop an effective pruning system for new Latvian cultivars, which provides the highest yield and fruit quality, along with earlier start of production (Fig. 5). Vegetative growth is reduced if trees have higher yield, because the intake of nutrients is diverted to form fruit buds and fruits. For high fruit quality, in our climate is very important to create and maintain an open tree crown without very strong new growth.

\section{PLUM COMMERCIAL GROWING IN LATVIA}

Commercial production of plums in Latvia is relatively small, which is the smallest among fruit trees (Table 2). The main reason is the climate, which allows to grow a limited range of cultivars tolerating $-30{ }^{\circ} \mathrm{C}$ winter temperatures, which occur about every five years, and also temperature fluctuations in late winter. With a right choice of site, cultivars and orchard management, plums can give high yields in larger commercial orchards.

Plums are grown mostly for fresh consumption, while a small part is used for jams, yoghurt and ice-cream additives. Fruits are sold mostly in smaller shops, markets and at farms. Only 2-5 cultivars are available in the supermarkets, of which the most popular are 'Kometa' (Fig. 6) and 'Victoria'.

About 20 cultivars are grown commercially (Table 3). The share of the six most popular plum cultivars ('Kometa',

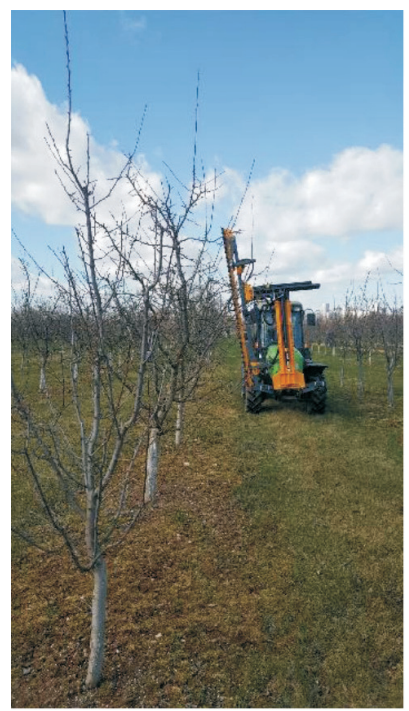

Fig. 5. Mechanical pruning of plums on $P$. cerasifera rootstocks.

Table 2

AREAS OF COMMERCIALLY GROWN FRUIT TREES IN LATVIA (YEAR 2018)

\begin{tabular}{lccc}
\hline \multicolumn{1}{c|}{ Crop } & Total area (ha) & Including organic (ha) \\
\hline Apples & 2844.17 & 434.47 \\
Pears & 155.95 & 9.8 \\
Plums & $\mathbf{9 5 . 2 2}$ & $\mathbf{2 6 . 4}$ \\
Cherries & 121.98 & 12.37
\end{tabular}

Data from Rural Support Service about declared areas larger than 0.3 ha: http://www.lad.gov.lv/lv/statistika/platibu-maksajumi/periods-20042016/statistikas-dati-par-2018-gadu/

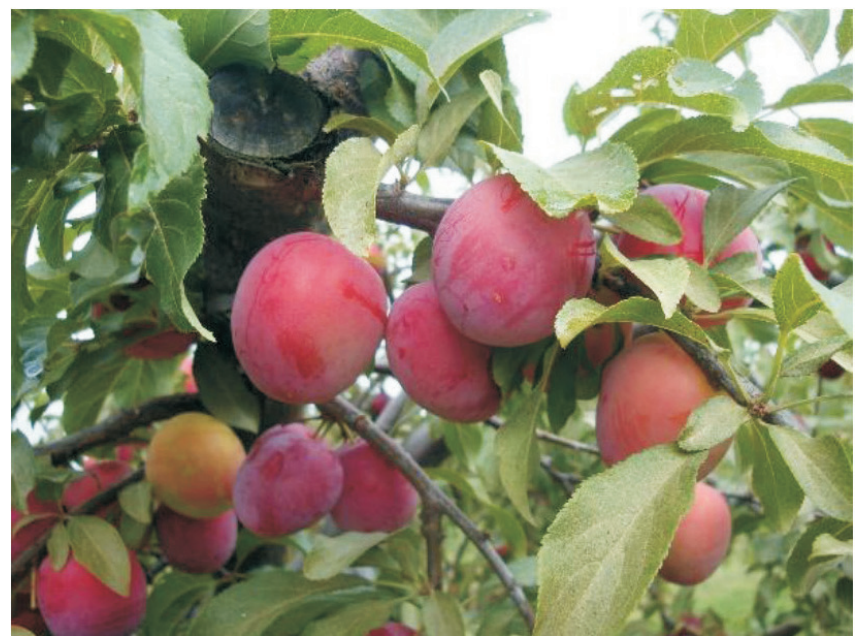

Fig. 6. 'Kometa': fruits.

'Victoria', 'Duke of Edinburgh', 'Reine-Claude d'Oullins', 'Skoroplodnaya', 'Julius') is $69 \%$ of the total plum production. In the last years, plantations of new cultivars developed at our institute have expanded, especially the early ripening cultivar 'Ance'. Also the Swedish cultivar 'Jubileum' has become more and more popular.

Other cultivars also commercially grown in Latvia are: 'Reine-Claude d'Althan', 'Aleinaya', 'The Czar', Experimentalfältets Sviskon', 'Emma Leppermann', 'Kārsavas', 
CHARACTERISATION OF PLUM CULTIVARS RECOMMENDED FOR GROWING IN LATVIA

\begin{tabular}{|c|c|c|c|c|c|c|}
\hline Cultivar, origin & Tree & Ripening time & Fruits & $\begin{array}{l}\text { Flowering time, } \\
\text { self-fertility }\end{array}$ & Production & $\begin{array}{l}\text { Winter-hardiness, } \\
\text { tolerance to diseases }\end{array}$ \\
\hline \multicolumn{7}{|c|}{ Recommended for commercial orchards in all Latvia: } \\
\hline $\begin{array}{l}\text { Ave } \\
\text { Estonia }\end{array}$ & $\begin{array}{l}\text { Medium vigour, up- } \\
\text { right }\end{array}$ & Early & $\begin{array}{l}\text { Medium, dark pur- } \\
\text { ple, flavour very } \\
\text { good, stone free }\end{array}$ & $\begin{array}{l}\text { Medium early, } \\
\text { self-sterile }\end{array}$ & $\begin{array}{l}\text { Productivity highly } \\
\text { dependent on } \\
\text { polleniser }\end{array}$ & $\begin{array}{l}\text { Tree hardy, flower } \\
\text { buds - medium } \\
\text { hardy; tolerant to } \\
\text { diseases }\end{array}$ \\
\hline $\begin{array}{l}\text { Kometa } \\
\text { (Kubanskaya } \\
\text { Kometa; } P \text {. salicina } \\
\times \text { cerasifera) } \\
\text { Russia } \\
\end{array}$ & $\begin{array}{l}\text { Medium vigour, } \\
\text { spreading }\end{array}$ & Very early & $\begin{array}{l}\text { Medium, raspberry } \\
\text { red, flavour good, } \\
\text { stone separates only } \\
\text { for tree-ripe fruits }\end{array}$ & $\begin{array}{l}\text { Very early, } \\
\text { self-sterile, poor } \\
\text { pollen }\end{array}$ & $\begin{array}{l}\text { Early and high, reg- } \\
\text { ular, very good } \\
\text { transportability }\end{array}$ & $\begin{array}{l}\text { Tree and buds } \\
\text { hardy; tolerant to } \\
\text { diseases }\end{array}$ \\
\hline $\begin{array}{l}\text { Lāse } \\
\text { Latvia }\end{array}$ & $\begin{array}{l}\text { Medium to vigor- } \\
\text { ous, upright, dense }\end{array}$ & Medium early & $\begin{array}{l}\text { Medium to large, } \\
\text { yellow, flesh firm, } \\
\text { flavour medium, } \\
\text { freestone }\end{array}$ & $\begin{array}{l}\text { Late, self-sterile, } \\
\text { poor pollen }\end{array}$ & $\begin{array}{l}\text { Productivity highly } \\
\text { dependent on } \\
\text { polleniser; poor } \\
\text { transportability }\end{array}$ & $\begin{array}{l}\text { Hardy; medium tol- } \\
\text { erant to diseases }\end{array}$ \\
\hline $\begin{array}{l}\text { Perdrigon } \\
\text { Western Europe }\end{array}$ & $\begin{array}{l}\text { Medium vigour, up- } \\
\text { right spreading }\end{array}$ & Medium late & $\begin{array}{l}\text { Medium, dark pur- } \\
\text { plish blue, flavour } \\
\text { mediocre, stone sep- } \\
\text { arates only for } \\
\text { tree-ripe fruits }\end{array}$ & $\begin{array}{l}\text { Medium late, } \\
\text { self-fertile, good } \\
\text { polleniser }\end{array}$ & $\begin{array}{l}\text { Productive, regular } \\
\text { yields }\end{array}$ & $\begin{array}{l}\text { Tree and flower } \\
\text { buds hardy; toler- } \\
\text { ance to diseases } \\
\text { good to medium }\end{array}$ \\
\hline $\begin{array}{l}\text { Skoroplodnaya } \\
\text { Russia } \\
(P . \text { salicina })\end{array}$ & $\begin{array}{l}\text { Vigorous, needs } \\
\text { regular heading } \\
\text { back of shoots and } \\
\text { crown renewal }\end{array}$ & Early & $\begin{array}{l}\text { Medium, bright red, } \\
\text { flavour good, stone } \\
\text { small, semi-free; do } \\
\text { not crack in rainy } \\
\text { weather }\end{array}$ & $\begin{array}{l}\text { Very early, } \\
\text { self-sterile, poor } \\
\text { pollen }\end{array}$ & $\begin{array}{l}\text { Very early and } \\
\text { good, but depends } \\
\text { on flower bud win- } \\
\text { ter damages; good } \\
\text { transportability }\end{array}$ & $\begin{array}{l}\text { Hardy in continetal } \\
\text { winters, suceptible } \\
\text { in thaws; tolerant to } \\
\text { diseases }\end{array}$ \\
\hline $\begin{array}{l}\text { Victoria } \\
\text { United Kingdom }\end{array}$ & $\begin{array}{l}\text { Medium vigour, } \\
\text { needs regular crown } \\
\text { renewal }\end{array}$ & Medium late & $\begin{array}{l}\text { Medium, } \\
\text { over-colour dark } \\
\text { pink, flavour good, } \\
\text { freestone }\end{array}$ & $\begin{array}{l}\text { Medium early, } \\
\text { self-fertile, good } \\
\text { polleniser }\end{array}$ & $\begin{array}{l}\text { Very early, produc- } \\
\text { tive, holds well on } \\
\text { tree }\end{array}$ & $\begin{array}{l}\text { Hardy, if high yields } \\
\text { are thinned; tolerant } \\
\text { to fruit rot }\end{array}$ \\
\hline \multicolumn{7}{|c|}{ Recommended for best orchard sites: } \\
\hline $\begin{array}{l}\text { Duke of Edinburgh } \\
\text { (Prince of Wales) } \\
\text { United Kingdom }\end{array}$ & $\begin{array}{l}\text { Vigorous, upright } \\
\text { spreading, needs } \\
\text { regular crown re- } \\
\text { newal }\end{array}$ & Medium late & $\begin{array}{l}\text { Over medium size, } \\
\text { dark purplish with } \\
\text { bloom, flavour } \\
\text { good, stone separa- } \\
\text { tion poor } \\
\end{array}$ & $\begin{array}{l}\text { Medium early, } \\
\text { self-fertile, good } \\
\text { polleniser }\end{array}$ & Early and good & $\begin{array}{l}\text { Medium, better if } \\
\text { high yields are } \\
\text { thinned; rather sus- } \\
\text { ceptible to fruit rot }\end{array}$ \\
\hline $\begin{array}{l}\text { Jubileum } \\
\text { Sweden }\end{array}$ & $\begin{array}{l}\text { Very vigorous, } \\
\text { needs careful train- } \\
\text { ing }\end{array}$ & Medium & $\begin{array}{l}\text { Large to very large, } \\
\text { dark purplish, fla- } \\
\text { vour good; stone } \\
\text { semi-free, rather } \\
\text { thich skin }\end{array}$ & $\begin{array}{l}\text { Medium early, par- } \\
\text { tially self-fertile }\end{array}$ & $\begin{array}{l}\text { High, needs irriga- } \\
\text { tion for good quality }\end{array}$ & $\begin{array}{l}\text { Hardy (tested } \\
\text { short-term); medium } \\
\text { tolerant to diseases }\end{array}$ \\
\hline $\begin{array}{l}\text { Julius } \\
\text { Estonia }\end{array}$ & Medium to small & Early & $\begin{array}{l}\text { Medium, purplish or } \\
\text { pink, flavour very } \\
\text { good, stone } \\
\text { semi-free }\end{array}$ & $\begin{array}{l}\text { Medium early, } \\
\text { self-sterile }\end{array}$ & Good, rather regular & $\begin{array}{l}\text { Medium hardy; sus- } \\
\text { ceptible to shot-leaf }\end{array}$ \\
\hline $\begin{array}{l}\text { Kijevas Vēlā } \\
\text { Ukraine }\end{array}$ & Medium, spreading & Medium late & $\begin{array}{l}\text { Large, dark purplish } \\
\text { blue, flavour very } \\
\text { good, stone } \\
\text { semi-free }\end{array}$ & $\begin{array}{l}\text { Medium late, } \\
\text { self-sterile }\end{array}$ & Good & $\begin{array}{l}\text { Medium hardy; sus- } \\
\text { ceptible to fruit rot } \\
\text { after cracking in } \\
\text { rain }\end{array}$ \\
\hline $\begin{array}{l}\text { Minjona } \\
\text { Latvia }\end{array}$ & $\begin{array}{l}\text { Small, spreading, } \\
\text { needs regular crown } \\
\text { renewal }\end{array}$ & Medium early & $\begin{array}{l}\text { Medium or smaller, } \\
\text { dark brownish pur- } \\
\text { ple, flavour good, } \\
\text { freestone }\end{array}$ & $\begin{array}{l}\text { Medium early, fully } \\
\text { or partly self-fertile }\end{array}$ & $\begin{array}{l}\text { Early and good, reg- } \\
\text { ular; ripe fruits fall } \\
\text { easily }\end{array}$ & $\begin{array}{l}\text { Hardy; medium tol- } \\
\text { erant to diseases }\end{array}$ \\
\hline $\begin{array}{l}\text { Oda } \\
\text { Ukraine }\end{array}$ & $\begin{array}{l}\text { Rather small, com- } \\
\text { pact; needs regular } \\
\text { crown renewal }\end{array}$ & Medium early & $\begin{array}{l}\text { Medium, dark blue, } \\
\text { flavour good, stone } \\
\text { semi-free, stone tip } \\
\text { often breaks }\end{array}$ & Early, self-sterile & $\begin{array}{l}\text { Early and good, reg- } \\
\text { ular }\end{array}$ & $\begin{array}{l}\text { Tree medium hardy, } \\
\text { flower buds hardy; } \\
\text { medium tolerant to } \\
\text { diseases }\end{array}$ \\
\hline $\begin{array}{l}\text { Ontario } \\
\text { USA }\end{array}$ & Medium to vigorous & Early & $\begin{array}{l}\text { Large, greenish yel- } \\
\text { low, flavour good, } \\
\text { freestone }\end{array}$ & $\begin{array}{l}\text { Late, fully or partly } \\
\text { self-fertile }\end{array}$ & Good, regular & $\begin{array}{l}\text { Medium hardy, me- } \\
\text { dium tolerant to dis- } \\
\text { eases }\end{array}$ \\
\hline
\end{tabular}


T a ble 3 (continued)

\begin{tabular}{|c|c|c|c|c|c|c|}
\hline Cultivar, origin & Tree & Ripening time & Fruits & $\begin{array}{l}\text { Flowering time, } \\
\text { self-fertility }\end{array}$ & Production & $\begin{array}{l}\text { Winter-hardiness, } \\
\text { tolerance to diseases }\end{array}$ \\
\hline $\begin{array}{l}\text { Renklod Ranny } \\
\text { Donetsky } \\
\text { Ukraine }\end{array}$ & Medium, spreading & Medium early & $\begin{array}{l}\text { Large, light yellow } \\
\text { with blush, flavour } \\
\text { good, stone separa- } \\
\text { tion good for } \\
\text { thinned fruits }\end{array}$ & Early, self-sterile & $\begin{array}{l}\text { Early and good, reg- } \\
\text { ular; transportability } \\
\text { poor }\end{array}$ & $\begin{array}{l}\text { Medium hardy; } \\
\text { rather susceptible to } \\
\text { fruit rot }\end{array}$ \\
\hline $\begin{array}{l}\text { Reine-Claude } \\
\text { d'Oullins } \\
\text { France }\end{array}$ & $\begin{array}{l}\text { Very vigorous, up- } \\
\text { right spreading }\end{array}$ & Medium early & $\begin{array}{l}\text { Medium to large, } \\
\text { greenish yellow, fla- } \\
\text { vour very good, } \\
\text { clingstone }\end{array}$ & $\begin{array}{l}\text { Medium late, } \\
\text { self-fertile, good } \\
\text { pollinator }\end{array}$ & $\begin{array}{l}\text { Late start of produc- } \\
\text { tion, productive; } \\
\text { transportability } \\
\text { poor }\end{array}$ & $\begin{array}{l}\text { Medium hardy; sus- } \\
\text { ceptible to fruit rot } \\
\text { when cracking }\end{array}$ \\
\hline $\begin{array}{l}\text { Sentyabrskaya } \\
\text { Ukraine }\end{array}$ & $\begin{array}{l}\text { Small or medium, } \\
\text { upright spreading }\end{array}$ & Medium late & $\begin{array}{l}\text { Medium to large, } \\
\text { dark blue with } \\
\text { bloom, flavour good } \\
\text { to very good, free- } \\
\text { stone }\end{array}$ & $\begin{array}{l}\text { Medium late, } \\
\text { self-sterile }\end{array}$ & Early and good & $\begin{array}{l}\text { Medium hardy } \\
\text { (short-term data); } \\
\text { susceptible to fruit } \\
\text { rot when cracking }\end{array}$ \\
\hline $\begin{array}{l}\text { Stanley } \\
\text { USA }\end{array}$ & $\begin{array}{l}\text { Medium, upright, } \\
\text { later upright spread- } \\
\text { ing }\end{array}$ & Very late & $\begin{array}{l}\text { Medium to large, } \\
\text { dark purple, dark } \\
\text { purple with bloom, } \\
\text { flavour good or very } \\
\text { good, freestone }\end{array}$ & $\begin{array}{l}\text { Late, partly } \\
\text { self-fertile }\end{array}$ & $\begin{array}{l}\text { Early and good, reg- } \\
\text { ular; transportability } \\
\text { good }\end{array}$ & $\begin{array}{l}\text { Hardy, but needs a } \\
\text { long growth season }\end{array}$ \\
\hline $\begin{array}{l}\text { Zarechnaya } \\
\text { Rannaya } \\
\text { Russia }\end{array}$ & $\begin{array}{l}\text { Vigorous, spread- } \\
\text { ing, sparse }\end{array}$ & Early & $\begin{array}{l}\text { Medium to large, } \\
\text { dark purplish, fla- } \\
\text { vour good to very } \\
\text { good, freestone }\end{array}$ & Early, self-sterile & $\begin{array}{l}\text { Early, productivity } \\
\text { differs between or- } \\
\text { chard sites }\end{array}$ & $\begin{array}{l}\text { Hardy (short-term } \\
\text { data) }\end{array}$ \\
\hline \multicolumn{7}{|l|}{ Perspective cultivars: } \\
\hline $\begin{array}{l}\text { Adelyn } \\
\text { Latvia }\end{array}$ & $\begin{array}{l}\text { Medium, upright } \\
\text { spreading, easy } \\
\text { training }\end{array}$ & Medium early & $\begin{array}{l}\text { Large, yellow with } \\
\text { blush, freestone; } \\
\text { good storage }\end{array}$ & $\begin{array}{l}\text { Medium early, } \\
\text { self-sterile }\end{array}$ & $\begin{array}{l}\text { Early, high, regular; } \\
\text { transportabilit y me- } \\
\text { dium }\end{array}$ & $\begin{array}{l}\text { Hardy (short-term } \\
\text { data); tolerant to } \\
\text { diseases }\end{array}$ \\
\hline $\begin{array}{l}\text { Ance } \\
\text { Latvia }\end{array}$ & $\begin{array}{l}\text { Vigorous, upright } \\
\text { spreading, with } \\
\text { good branching }\end{array}$ & Very early & $\begin{array}{l}\text { Medium to large, } \\
\text { yellow with blush, } \\
\text { flavour good, free- } \\
\text { stone }\end{array}$ & $\begin{array}{l}\text { Medium early, } \\
\text { partly self-fertile } \\
\text { (short-term data) }\end{array}$ & $\begin{array}{l}\text { Early, high, regular; } \\
\text { holds well on tree }\end{array}$ & $\begin{array}{l}\text { Hardy; medium tol- } \\
\text { erant to diseases }\end{array}$ \\
\hline $\begin{array}{l}\text { Laine } \\
\text { Latvia }\end{array}$ & $\begin{array}{l}\text { Medium, spreading, } \\
\text { with good branching }\end{array}$ & Medium late & $\begin{array}{l}\text { Very large, purple } \\
\text { with pale yellow } \\
\text { flesh, firm, free- } \\
\text { stone }\end{array}$ & Medium early & High & $\begin{array}{l}\text { Hardy (short-term } \\
\text { data); medium toler- } \\
\text { ant to diseases }\end{array}$ \\
\hline $\begin{array}{l}\text { Lotte } \\
\text { Latvia }\end{array}$ & Medium, spreading & Medium late & $\begin{array}{l}\text { Medium, dark pur- } \\
\text { plish blue, sweet, } \\
\text { freestone }\end{array}$ & $\begin{array}{l}\text { Medium late, partly } \\
\text { self-fertile } \\
\text { (short-term data }\end{array}$ & $\begin{array}{l}\text { Early, medium pro- } \\
\text { ductive }\end{array}$ & $\begin{array}{l}\text { Satisfactory only in } \\
\text { best locations, trunk } \\
\text { susceptible to winter } \\
\text { injury; medium tol- } \\
\text { erant to diseases }\end{array}$ \\
\hline $\begin{array}{l}\text { Renklod Sovetsky } \\
\text { Russia }\end{array}$ & $\begin{array}{l}\text { Medium, uprigh } \\
\text { spreading }\end{array}$ & Medium early & $\begin{array}{l}\text { Large, dark purple } \\
\text { with bloom, firm, } \\
\text { flavour good, free- } \\
\text { stone }\end{array}$ & $\begin{array}{l}\text { Medium early, } \\
\text { self-sterile }\end{array}$ & $\begin{array}{l}\text { Early, good; very } \\
\text { good transportabil- } \\
\text { ity }\end{array}$ & $\begin{array}{l}\text { Medium hardy and } \\
\text { medium tolerant to } \\
\text { diseases (short-term } \\
\text { data) }\end{array}$ \\
\hline $\begin{array}{l}\text { Sonora } \\
\text { Latvia }\end{array}$ & $\begin{array}{l}\text { Medium, easy to } \\
\text { train, needs regular } \\
\text { crown renewal }\end{array}$ & Medium late & $\begin{array}{l}\text { Large, purplish with } \\
\text { bloom, flavour good } \\
\text { for tree-ripe fruits, } \\
\text { stone semi-free }\end{array}$ & $\begin{array}{l}\text { Medium early, } \\
\text { self-fertile }\end{array}$ & $\begin{array}{l}\text { Early, good, regular; } \\
\text { needs several pick- } \\
\text { ings }\end{array}$ & $\begin{array}{l}\text { Medium hardy and } \\
\text { medium tolerant to } \\
\text { diseases }\end{array}$ \\
\hline $\begin{array}{l}\text { Tegera } \\
\text { Germany }\end{array}$ & $\begin{array}{l}\text { Rather vigorous, up- } \\
\text { right to spreading }\end{array}$ & Medium early & $\begin{array}{l}\text { Medium to large, } \\
\text { purplish blue with } \\
\text { bloom, firm and } \\
\text { juicy, freestone }\end{array}$ & $\begin{array}{l}\text { Medium late, } \\
\text { self-fertile }\end{array}$ & $\begin{array}{l}\text { Early, high, regular, } \\
\text { very transportable, } \\
\text { hold well on tree }\end{array}$ & $\begin{array}{l}\text { Medium hardy and } \\
\text { medium tolerant to } \\
\text { diseases (short-term } \\
\text { data) }\end{array}$ \\
\hline $\begin{array}{l}\text { Zane } \\
\text { Latvia }\end{array}$ & $\begin{array}{l}\text { Spreading, with } \\
\text { very nice, healthy } \\
\text { foliage }\end{array}$ & Early & $\begin{array}{l}\text { Large, light purple, } \\
\text { flesh greenish, very } \\
\text { tasty, stone } \\
\text { semi-free }\end{array}$ & Medium & $\begin{array}{l}\text { Medium productive, } \\
\text { regular, needs sev- } \\
\text { eral pickings }\end{array}$ & $\begin{array}{l}\text { Medium hardy and } \\
\text { medium tolerant to } \\
\text { diseases (short-term } \\
\text { data) }\end{array}$ \\
\hline
\end{tabular}


'Latvijas Dzeltenā Olplūme', 'Grand Duke', 'Mirabelle de Nancy', 'Okskaya', 'Ontario', 'Renklod Ulyanishcheva', 'Suhkruploom', 'Tragedy', 'Reine Claude Verte', etc. Diploid plum cultivars include also 'Mara', 'Naidyona', 'Spīdola', pollenisers 'Alvis' and 'Agrā Dzeltenā' (Kaufmane, 2015).

The main plum season in Latvia starts at the end of July (diploid plums and some domestic plums - 'Aleinaya', 'Polli Varane', 'Ance', 'Startovaya'). Most of the cultivars are harvested in August and begining of September (also the most popular — 'Victoria'). The latest cultivars that are possible to grow in Latvia, are 'Stanley', 'Grand Duke', and 'Giant', which ripen in the end of September or begining of October.

The productivity in the best large orchards in Soviet times was $12-13 \mathrm{t} / \mathrm{ha}$. Then the fruits were mostly grown for processing (jams, juices, and compotes), and prices were very low. At present, statistical data of yields in Latvia are imcomplete, as well as data about the local market, because plums are sold mostly on farms and at farmer markets. Only a small share goes to supermarkets.

Questioning of the largest growers showed that the average yield of mature trees is $20-25 \mathrm{~kg} /$ tree $(12-14 \mathrm{t} / \mathrm{ha})$ for domestic plums and 35-40 kg/tree (19-22 t/ha) for the diploid plum 'Kometa'. At our Institute the average yield is $\sim 30 \mathrm{~kg} /$ tree $(\sim 20 \mathrm{t} / \mathrm{ha})$. The most productive cultivars are 'Sonora' (max. 46 kg/tree), 'Ance' (max. 70 kg/tree), 'Jubileum' (max. $75 \mathrm{~kg} /$ tree) and 'Victoria' (max. $67 \mathrm{~kg} /$ tree).

Price depends on the the annual yield. In 2018, it was 1.3-1.7 EUR/kg for fruits were sold to supermarkets. Imported plums (Poland, etc.) are cheaper (0.6-0.8 EUR/kg) and create hard competition. When the plums are sold on a farm or at a farmers market, the price varies from $2 \mathrm{EUR} / \mathrm{kg}$ (early cvs.) to $1 \mathrm{EUR} / \mathrm{kg}$ in the main season.

\section{MAIN PLUM DISEASES IN LATVIA}

Virus diseases. Plum pox virus (PPV) or sharka is one of the most devastating viruses to plum production in the world. In the last 30 years, it has spread rapidly, and today PPV can be found in nearly all plum growing regions worldwide (Hartman and Neumüller, 2013). In Latvia it is in the list of quarantine diseases, and the Plant Protection Service carries out regular monitoring of orchards. In Latvia PPV was found in a few cases in home gardens and collections, but not in commercial plantations.

To evaluate the occurrence of Plum pox virus (PPV) and eight other viruses infecting Prunus, a large-scale survey and sampling in Latvian plum orchards was carried out. Occurrence of Apple mosaic virus (ApMV), Prune dwarf virus $(P D V)$, Prunus necrotic ringspot virus (PNRSV), and Apple chlorotic leaf spot virus (ACLSV) on plums also was investigated by RT-PCR and DAS ELISA detection methods. The study demonstrated that stone fruit viruses are relatively not widespread in plum orchards in Latvia and that the commonly grown genotypes are infected with one or more of the tested viruses. In the future, the implementation of a programme to produce and propagate virus free planting material, along with the establishment of virus free planting material collections and certification programmes in the country, will play the key role for the containment of the spread of these viruses in the orchards (Gospodaryk et al., 2013).

Bacterial diseases. Bacterial diseases are economically important and widespread on stone fruits worldwide. The bacterial diseases of stone fruits have not been studied in Latvia, and the identification of causal agents has not been carried out previously. Eleven farms were surveyed in 2008-2011 to determine and evaluate the occurrence of pathogenic Pseudomonas syringae on plums (Prunus domestica L.) in different regions of Latvia. Pathogenic P. syringae was detected in samples only from three farms. The low occurrence of pathogenic $P$. syringae showed that severe symptoms observed on plums in orchards are also caused by other plant pathogens (Konavko et al., 2017).

Fungal diseases. Plum rust (caused by Tranzschelia prunispinosae (Pers.) Dietel.) in some years spreads in commercial plantations, especially when no phytosanitary prophylaxis is done. In the case of widespread infection it may be harmful to trees.

Shot leaf disease (caused by Wilsonomyces carpophilus Lev. syn. Stigmina carpophila (Lev.) M. B. Ellis) is common in commercial orchards, and damaging in some cases.

Silver leaf disease (caused by Chondrostereum purpureum (Pers.) Pouzar) spreads after unfavourable winters, usually on less hardy cultivars. In Latvia it is considered as one of the most dangerous diseases, as it damages the whole tree, including wood.

Common fruit rot (caused by: Monilinia fructigena Honey) is widespread, especially in moist summers, in poorly managed orchards.

Plum pockets (caused by Taphrina pruni Tul.) is rare in Latvia, but is a potentially dangerous disease as it may completely destroy the yield.

\section{MAIN PLUM PESTS IN LATVIA}

Plum sawfly (Hoplocampa flava L.; Hoplocampa minuta Christ.) is widely found in Latvia, which makes impossible successful plum growing without pesticides.

Plum codling moth (Grapholita funebrana Treitchke) was detected in the 1980s. In some years it can be very widespread and can destroy the entire yield.

Plum aphids (Hyalopterus pruni Geoffr.) are widely spread in Latvia and may cause significant damages, as in larger numbers can cause premature leaf drop and obstruction of new growth. They especially cause problems in organic or- 
chards where insecticides are not used and if reeds are growing nearby.

Fruit-tree red spider mite (Panonychus ulmi C. L. Koch.) is widely spread in some years. There is lack of available acaricides and paraffine oil on the Latvian market.

\section{FRUIT QUALITY AND POST-HARVEST}

For all new cultivars, including introduced cultivars, detailed quality asssesment is done before their registration or recommendation for commercial plantations. The cultivars are tested for the following parameters: soluble solids, titrable acids, vitamin $\mathrm{C}$, flesh firmness, as well as changes of firmness in common storage. Sensory analyses also are performed. It was found that the indices are influenced both by the cultivar and weather conditions of the year, and thus the parameters vary significantly between years. The fruit harvest date is especially important, i.e. the stage of fruit maturity during picking and analyses (Kaufmane et al., 2010).

To examine the possibilities of prolonging plum storage time, trials were carried out at the Institute using 1-methylcyclopropene $(1-\mathrm{MCP})-12 \mathrm{~h}$ at $3{ }^{\circ} \mathrm{C}, 1-\mathrm{MCP}$ in concentration $0.520 \mu \mathrm{l} 1-1$. Effect of 1-MCP on physical and chemical indices and sensory quality of the plum (Prunus domestica L.) cultivars was evaluated. After four weeks of storage, significant differences were found between cultivars. For some cultivars 1-MCP treatment gave a positive effect on fresh weight and flesh firmeness losses, as well as on preservation of colour, taste and aroma. However, most cultivars fruits after 1-MCP treatment had reduced sweetness (based on the Hedonic scale evaluation). Significant differences of results were observed between years (Radenkovs et al., 2015).

Recently, research was conducted on potential use of plum stones as a by-product. A large amount of hexaploid and diploid cultivars in the institute collection was examined. It was concluded that different parts of the stone contain fatty acids, tocopherols, tocotrienols and carotenoids, their content significantly differing between cultivars (Gornas et al., 2015).

\section{FUTURE PROSPECTS}

Although at present the scale of plum growing in Latvia is small, the future prospects are rather good, because:

- In recent years, the area of commercial plantations (integrated and biological) has increased;

- The variety available has increased - new, better cultivars recommended by the Institute of Horticulture have been planted;

- Growing technologies have changed and more attention is paid to fruit quality (in some commercial orchards plantations were established with modern tree support systems - espaliers);
- Consumers more often choose local fruits;

- Processing enterprises have developed, which look for new ways of plum products — puree for children "Rūdolfs", dried and candied plums, low-fat ice creams, etc.

\section{REFERENCES}

Anonymus (1870-1871). Katalog von C. W. Schoch. Riga. 32 S.

Dēḳena, Dz., Poukh, E. V. Kahu, K. Laugale, V. Alsiṇa. I. (2017). Influence of rootstocks on plum productivity in different growing regions. Proc. Latvian Acad. Sci., Section B, 71 (3), 233-236.

Dēḳena, Dz., Alsiṇa, I. (2017). Plūmju potcelmu izvērtējums [Evaluation of plum rootstocks]. Grām.: Zinātniski praktiskās konferences "Līdzsvarota Lauksaimniecība" raksti [Proceedings of the Applied Science Conference "Balanced Agriculture”]. Jelgava, 88-92 (in Latvian).

Dēķens, U. (1999). Kirš̌u un plūmju grāmata [A Book of Plums and Cherries]. Avots, Rīga. 247 lpp. (in Latvian).

Feldmane, D., Strautiņa, S. Ikase, L. (2015). Aug̣̣kkopības biolog̣iskie pamati [Biologial background of fruit growing]. Grām.: Ikase, L. (ed.). Auglıopība [Fruit Growing]. Latvijas Valsts Augḷkopības institūts, 25.-49. 1pp. (in Latvian).

Górnaś, P., Mišina, I., Grāvīte, I., Lācis, G., Radenkovs, V., Olšteine, A., Segliņa, D., Kaufmane, E., Rubauskis, E. (2015). Composition of tocochromanols in the kernels recovered from plum pits: The impact of the varieties and species on the potential utility value for industrial application. Eur. Food Res. Technol., 241 (4), 513-520.

Gospodaryk, A., Moročko-Bičevska, I. Pūpola, N., Kāle, A. (2013). Occurrence of stone fruit viruses in plum orchards in Latvia. Proc. Latvian Acad. Sci., Section B, 67 (2), 116-123.

Gravite, I., Kaufmane, E. (2017). Evaluation of German plum selection in Latvia. Proc. Latvian Acad. Sci., Section B, 71 (3), 166-172.

Gravite, I., Skrīvele, M. (2015). Plūmju veidošanas īpatnības [Specifics of plum-tree training]. In: Ikase, L. (ed.). Auglkopība [Fruit Growing]. Latvijas Valsts Augḷkopības institūts, 362. lpp. (in Latvian).

Grāvīte, I., Kaufmane, E. (2013). Results of pollination studies of some new plum cultivars in Latvia. Acta Horticult., 976, 121-127.

Gronskis, I., Ūdris, J. (eds.). (1988). Auglkopja rokasgrāmata [Fruit Grower's Handbook]. Avots, Rīga. 247 lpp. (in Latvian).

Hartman, W., Neumüller, M. (2013). Next generation of European plum cultivars resistant to Plum Pox Virus. Acta Horticult., 985, 149-154.

Ikase, L. (1991). Kaukāza plūmes, hibrīdplūmes un citas [Myrobalan plums, hybrid plums and others]. Dārzs un Drava, No. 1-2, 4-5 (in Latvian).

Ikase, L. (1993). Prunus cerasifera Ehrh. un tās starpsugu hibrīdi kā jauns gēnu avots plūmju selekcijai Latvijā. Disertācija bioloğijas doktora grāda iegūšanai, Latvijas Universitāte [Prunus cerasifera Ehrh. and its inter-species hybrids a new source of genes for plum breeding in Latvia. Doctoral Thesis, University of Latvia]. 155 lpp. (in Latvian).

Ikase, L. (1998). Winterhardiness of diploid plums in Latvia. Horticulture and Vegetable Growing: Scientific Works of the Lithuanian Institute of Horticulture and Lithuanian University of Agriculture, 17 (3), 135-142.

Ikase, L., Kaufmane, E. (1994). Jaunas agrīnas plūmju šķirnes [New early plum cultivars]. Dārzs un Drava, No. 1, 2. 1pp. (in Latvian).

Jekovičs, V. (1972). Plūmes [Plums]. Liesma, Rīga. 174. lpp. (in Latvian).

Jekovičs, V. (1988). Plūmes pēc 1986./87. gada ziemas [Plums after the winter of 1986/87]. Dārzs un Drava, No. 10, 8.-11. 1pp. (in Latvian).

Kaufmane, E., Ikase, L. Trajkovski, V. (2003). Evaluation of Swedish plum varieties and hybrids in Sweden and Latvia. Horticulture and Vegetable growing: Scientific Works of the Lithuanian Institute of Horticulture and Lithuanian University of Agriculture, 22 (1), 62-73.

Kaufmane, E., Ikase, L. Seglina, D. (2010). Pomological characteristics of plum table cultivars in Latvia. Acta Horticult., 874, 337-341. 
Kaufmane, E., Skrivele, M., Rubauskis, E. (2007). The influence of different rootstocks on the growth and yield of plum cultivars. Acta Horticult., 734, 387-391.

Kaufmane, E., Skrivele M., Rubauskis E., Ikase L. (2007a). The yield and fruit quality of two plum cultivars on different rootstocks. Horticulture and Vegetable Growing: Scientific Works of the Lithuanian Institute of Horticulture and Lithuanian University of Agriculture, 26 (3), 10-15.

Kaufmane, E., Trajkovski, V., Lacis, G., Ikase, L. (2002). Evaluation and characterisation of plum genetic resources in Sweden and Latvia. Acta Horticult., 577, 207-215.

Kaufmane, E. (2015). Plūmes [Plums]. Grām.: Ikase L. (ed.). Augḷopība [Fruit Growing]. Latvijas Valsts Aug̣̣kopības institūts, 175.-180. lpp. (in Latvian).

Kaufmane, E., Grāvīte, I., Trajkovski, V. (2012). Results of Latvian plum breeding programme. Acta Horticult., 968, 55-60.

Kārkliņš, J. (1958). Ziemcietīgi augḷu dārzi [Winter-hardy orchards]. Latvijas Valsts izdevniecība, Rīga. 78. lpp. (in Latvian).

Kārkliṇš, J. (1966). Auglkopība [Fruit Growing]. Zvaigzne, Rīga. 671 lpp. (331.-350. 1pp.) (in Latvian).

Kārkliņš, J., Skrīvele, M. Kaufmane, E. Ikase, L. (2007). Plūmju šķirnes: Latvijas pomologija [Plum cultivars: Latvian pomology]. Reneprint, Rīga. 204 lpp. (in Latvian).

Klevers, S. (1881). Zemkopja augḷ koku dārzs [Farmer's orchard]. Jelgava. 95. 1pp. (in Latvian).

Konavko, D., Jundzis, M., Moročko-Bičevska, I. (2017). Pseudomonas syringae sastopamība kaulenkoku dārzos Latvijā [Occurrence of pathogenic Pseudomonas syringae on stone fruits in Latvia]. Grām.: Ražas svētki "Vecauce - 2017": Lauksaimniecības zinātne Latvijas simtgades gaidās. Ltvijas Lauksaimniecības universitāte, Jelgava, 37.-40. 1pp. (in Latvian).

Kota, I., Lacis, G. (2013). Evaluation of self-incompatibility locus diversity of domestic plum (Prunus domestica L.) using DNA-based S-genotyping. Proc. Latvian Acad. Sci., Section B, 67 (2), 109-115.

Mežapuķe, J. (1969). Selekcionāra sniegums [Breeder's achievements]. Liesma, Rīga. 138 lpp. (in Latvian).

Nilsson, A. (1989). Our Pear, Plum and Cherry Cultivars. Karlebo, Stockholm. 370 pp. (in Swedish).
Penğerots-Svešais, J. (1914). Augḷu dārzs [The fruit garden]. Grām.: Vadons zem- un dārzkopjiem. Otrs pārlabots un stipri paplašināts izdevums. Rīga, 274 lpp. (in Latvian)

Radenkovs, V., Kaufmane, E., Rubauskis, E., Seglina, D. (2015). Preliminary results of 1-methylcyclopropene influences on the quality of plums grown in Latvia. Proc. Latvian Acad. Sci., Section B, 70 (1), 21-28.

Skrīvele, M. (1982a). Nedaudz par plūmju šķirņu ziemcietību un ražību Pūrē [Some observations about winter-hardiness and productivity of plum cultivars in Pūre]. Dārzs un Drava, No. 5, 2. 1pp. (in Latvian).

Skrīvele, M. (1982b). Vēlreiz par plūmēm [Again about plums]. Dārzs un Drava, No. 10, 3-5 (in Latvian).

Skrīvele, M., Dēḳēna, Dz. (2017). Plūmes Igaunijā un Latvijā [Plums in Estonia and Latvia]. Agrotops, 11, 70-71 (in Latvian).

Skrīvele, M., Kaufmane, E., Ikase, L. (1999). 'Lāse' and 'Minjona' — two new promising Latvian plum varieties. In: Collection of Scientific Articles of the Conference "Fruit Growing Today and Tomorrow", September 4, 1998, Dobele, pp. 42-50.

Skrīvele, M., Rubauskis, E. (2015). Augḷu dārzu kopšana [Orchard managament]. Grām.: Ikase, L. (ed.). Augḷopība [Fruit Growing]. Latvijas Valsts Aug̣̣kopības institūts, 345.-364., 376.-380. 1pp. (in Latvian).

Spolītis, A. (1978). Nedaudz par plūmju selekciju [A little about plum breeding]. Dārzs un Drava, No. 5, 3-4 (in Latvian).

Spolītis, A., Romanovska, O., Kārkliṇš, J. (1955). Latvijas PSR tautas selekcijas aug̣ı koku šķirnes [Latvian SSR Fruit Tree Landraces]. LPSR Zinātṇu akadēmijas izdevniecība, Rīga, 57.-69. lpp. (in Latvian).

Sudrabs, J. (1914). Vai auglu koki var ražot katru gadu? [Can fruit trees yield every year?]. Ķeizariskās Krievijas Dārzkopības Biedrības Rīgas Nodaḷas Gada Grāmata. Rīga, 93. lpp.

Sudrabs, J. (1943). Augḷkopība [Fruit Growing]. Rīga. 532 lpp. (463.-473.) 1pp. (in Latvia).

Sudrabs, J. (1947). Augḷu dārzu atjaunošana un salā izturīgās augḷu koku škirnes [Renewal of orchards and winter-hardy fruit varieties]. Grām.: Latvijas Lauksaimniecības akadēmijas raksti. II sēj., 1. burtn. Latvijas Valsts izdevniecība, Rīga, 73.-80. lpp. (in Latvian).

Received 28 January 2019

Accepted in the final form 24 March 2019

\section{PLŪMJU IZPĒTE UN AUDZĒĚSANA LATVIJĀ}

Latvijā plūmes komerciāli audzētas jau pagājušajā gadsimtā. Sevišḳi stādījumi paplašinājās 20. gs. 20.-30. gados. Šajā laikā introducēja daudzas plūmju šķirnes, sevišḳi no Rietumeiropas. Pēc 1939./40., 1941./42., 1955./56., 1978./79. gada barga sala ziemām plūmju stādījumi ievērojami samazinājās, galvenokārt pietiekami ziemcietīgu šķirṇu trūkuma dēḷ. Tāpēc plūmju sortimenta paplašināšanai sāka ievest Krievijā, Baltkrievijā un Igaunijā selekcionētas šḳirnes. No vecajām škirnēm aktualitāti nav zaudējusi 'Latvijas Dzeltenā Olplūme'. Tā kādreiz bija ḷoti ražīga, izcēlās ar augstu ziemcietību un labu aug̣̦u kvalitāti. Diemžēl pēdējos gados kokaudzētavās savairojušies šīs škirnes ziemcietīgāki, bet mazražīgi kloni ar neapmierinošu augḷu kvalitāti. Tā kā Latvijas patēêtēji iecienījuši dzeltenās plūmes, šobrīd norit darbs pie ražīgāko klonu atlases no veciem piemājas dārziem un stādījumiem un to pavairošanas. 20. gadsimta vidū Latvijā sākās aktīva plūmju selekcija, krustojot izturīgākos genotipus ar augstas kvalitātes donoriem. Šĩ perioda škirnes 'Lāse' un 'Minjona' vēl joprojām tiek audzētas. Kopš 20. gs. 80. gadiem selekcijas darbs turpinās Dārzkopības institūtā. Krustojumi tika veikti galvenokārt ar heksaploīdajām plūmēm ar mērḳi iegūt lielaug̣̣u šķirnes ar labu garšu, kas ienākas dažādos laikos, īpaši koncentrējoties uz agrīnām un vidēji vēlām šḳirnēm. Jaunās institūtā selekcionētās šḳirnes 'Sonora', 'Ance', 'Adelyn' izceḷas ar labu augḷu kvalitāti un ražību. Pilnražas gados raža ir 15-20 kg, atsevišḳos gados — pat līdz $70 \mathrm{~kg}$ no koka.

Latvijā izplatītākais plūmju potcelms ir Kaukāza plūmes Prunus cerasifera Ehrh. ssp. divaricata C. K. Schneid.) sēklaudži, kas ir izturīgāki par Eiropā izmantoto kiršveida plūmi. Tiem ir laba saderība ar lielāko daḷu škirṇu, iznemot renklodes, koki labi aug dažādās augsnēs un ir izturīgi pret kaitēkḷiem un slimībām. Trūkums ir garais veǵetācijas periods, tāpēc aizkavējas uzpotēto šḳirṇu nobriešana, un tās var ciest salā; šie potcelmi veido daudz atvašu ap stumbru, īpaši, ja šķirnei ir nesaderība ar potcelmu. Dārzkopības institūtā ir izdalīts sēklaudzis (Prunus cerasifera un P. salicina ssp. ussuriensis hibrīds) ar augstu salcietību, kas nedaudz samazina koka augumu. Izmēǵinājumi ar vairākiem Rietumeiropā un Krievijā selekcionētiem potcelmiem nav devuši pozitīvus rezultātus un ražošanā nav ieviesti. Šobrīd Dobelē ierīkots jauns izmēgeinājums ar vairākām škirnēm uz Wangenheims potcelma, kā arī uz maza auguma potcelmiem VVA-1, Weiwa, S766 and M633. 
Plūmju komercaudzēěanas apjomi Latvijā ir salīdzinoši nelieli; platību ziṇā plūmes ieṇem pēdējo vietu starp augḷu kokiem. Pārsvarā tās tiek audzētas svaigam patērinam, nedaudz — ievārījumiem, jogurtu un saldējumu piedevām. Pieprasījums pēc plūmēm Latvijā ir, bet lielveikalos vietējie aug̣̣i praktiski nav pieejami. Izaudzētās plūmes tiek realizētas mazākos veikalos, tirgū vai uz vietas pie audzētājiem. To lielā mērā nosaka klimatiskie apstākḷi, jo vidēji ik pēc pieciem gadiem ziemā temperatūra pazeminās līdz $-30{ }^{\circ} \mathrm{C}$ un zemāk. Līdz ar to šobrīd tiek audzēts ierobežots šķinnu skaits. Komerciāli tiek audzētas apmēram 20 šķirnes, bet sešas populārākas škirnes veido $69 \%$ no kopējās plūmju stādījumu platības. Pēdējos gados paplašinās Dārzkopības institūtā selekcionēto šķirṇu, sevišķ agrīnās škirnes 'Ance', platíbas. 